ACTA THERIOLOGICA

Vol. 27, 6: 83-96, 1982

\title{
Carotenoid Contents in Mammals. II. Carotenoids of Some Vespertilionidae from the Seasonal Variation Aspect
}

\author{
Bazyli CZECZUGA \& Andrzej L. RUPRECHT
}

\begin{abstract}
Czeczuga B. \& Ruprecht A. L., 1982: Carotenoid contents in mammals. II. Carotenoids of some Vespertilionidae from the seasonal variation aspect. Acta theriol., 27, 6: 83-96 [With 8 Tables \& 3 Figs.].

Examination was made of carotenoid contents in the skin, muscles, liver and intestines of six Polish species of bats of the Vespertilionidae family from the aspects of sex and seasonal variation. Identification and division of carotenoids was carried out by means of chromatographic methods. In all the species examined maximum concentration of carotenoids occurs in the intestines and liver, with a lesser concentration in the muscles. A particulary distinct and successive decrease in carotenoid contents is evident at the beginning of hibernation in Eptesicus serotinus, whereas the total carotenoid contents in Myotis myotis, Myotis nattereri and Myotis daubentoni is higher towards the end of hibernation. This suggests that these species are able to make use of additional sources of food during the winter time.

[Dept. Biol., Medical Academy, Kilińskiego 1, 15-230 Białystok and Mammals Res. Inst., Polish Acad. Sci., 17-230 Białowieża, Poland]
\end{abstract}

\section{INTRODUCTION}

During the course of studies on the occurrence of carotenoids in different animals, including mammals (Czeczuga \& Malzahn, 1980; cf. also bibliography referred to in their paper) we became interested in bats. The Polish Vespertilionidae appeared particularly suitable for studies on differences in carotenoid content, on account of the fact that these species feed almost exclusively on insects and also hibernate. The results of preliminary examination of seasonal variation in carotenoid concentration in five species of bats (Czeczuga \& Ruprecht, 1981) encouraged us to look for an explanation of certain food relations between bats and their prey-insects. This appeared possible because of the good knowledge already obtained of the qualitative composition of body carotenoids in different species of insects (Feltwell, 1979; Czeczuga, 1976. $1980 \mathrm{a}, \mathrm{b})$ and also on account of the fact that the composition of the food consumed by the majority of insectivorous bats is also known (Nyholm, 1965; Brosset \& Deboutteville, 1966; Sologor \& Petrusenko, 1973; Bauerová, 1978; Krauss, 1978). We also wanted to establish whether there was a phenomenon of selective accumulation of certain carotenoids 
in the tissues of bats on the one hand, and on the other, whether carotenoids consumed with food are transformed into different forms which are not encountered in insects.

\section{MATERIALS AND METHODS}

A total of 23 adult individuals of bats from the following species were used for the studies: Myotis myotis (Borkhausen, 1797) -4 (2M and $2 \mathrm{~F}), M$. nattereri (Kuhl, 1818) $-3(2 \mathrm{M}$ and $1 \mathrm{~F}), M$. brandtii (Eversmann, 1845) $-4(\mathrm{M}), M$. daubentoni (Kuhl, 1819) - 5 (2M and 3F), Eptesicus serotinus (Schreber, 1774) -6 (4M, 1F and $1 \mathrm{~F}$ embryo) and Plecotus auritus (Linnaeus, 1758) -2 (1M and 1F). These individuals were caught on Nov. 21st, 1979 and Apr. 10th, 1980 in the bats' wintering place at Nietoperek (Gorzów Wielkopolski Palatinate). Four male individuals of Brandt's bat were caught on Apr. 10th, 1981 in the Szachownica Cave near Działoszyn (Sieradz Palatinate). The remaining E. serotinus material was caught at Białowieża - one male on Dec. 20th, 1979 and June 5th, 1981, and one male and one gestating female on June 13th, 1981.

Carotenoid contents were examined in the skin (with the exception of Brandits bat), muscles, liver and intestines. The tissues taken for examination were immersed in $95 \%$ acetone in dark glass bottles, to which nitrogen was next added, after which the bottles were kept in a refrigerator at a temperature of $-4^{\circ} \mathrm{C}$ until required. Separation of the different carotenoid pigments was carried out by means of column and thin layer chromatography. The material was previously hydrolyzed in $10 \% \mathrm{KOH}$ in a nitrogen atmosphere at room temperature for 24 hours. After hydrolysis the extract was transferred to a column filled with $\mathrm{Al}_{2} \mathrm{O}_{3}$. Column length varied from 15 to $25 \mathrm{~cm}$ (Quick-fit firm, England). The different fractions were eluted by means of different solvent systems, after which the eluent was evaporated and the residue dissolved in the appropriate solvent (Czeczuga \& Czerpak, 1976) in order to plot the absorption curve, the maxima of which served, inter alia, to identify the various carotenoids. The models of the firm of F. Hoffmann - La Roche, Basle, were used for $\beta$-carotene, canthaxanthin, lutein, zeaxanthin and astaxanthin. Absorption maxima were identified by the use of the Specol spectrophotometer.

In addition to column chromatography the acetone extract obtained was divided into various fractions by means of thin-layer chromatography. Glass plates measuring 15 by $40 \mathrm{~cm}$, the surface of which was covered with silicagel (firm of Merck) were used for this purpose, then using a special micropipette the acetone extract was placed on the starting line, employing various solvent systems as well (Czeczuga \& Czerpak, 1976). $R_{f}$ was next determined in accordance with principles in general use.

Carotenoids were identified on the basis of the absorption maxima of the various fractions, of $R_{f}$ value, of the epoxide test and also of the epiphase and hypophase relations obtained. The quantitative ratios of caretonoids were determined by Davies' method (Czeczuga \& Czerpak, 1976).

\section{RESULTS}

A total of 24 carotenoids were identified in the extracts examined, this number consisting of 2 carotenes and 22 xanthophylls. In relation 
to carotenoids qualitative differentiation, depending on the season, was found in individuals of the same species. These differences apply primarily to $\beta$-carotene, $\beta$-cryptoxanthin, isozeaxanthin and astaxanthin ester. Some of the xanthophylls, however, were found only in some of the bat species examined. Different carotenoids also dominated in different species and sometimes even in different tissues of the same individuals. This makes it necessary to discuss individual results.

In the case of Myotis myotis 19 carotenoids were identified, finding, as in the case of $M$. daubentoni, that rhodoxanthin was also present.

Table 1

Seasonal changes in carotenoids contents of Myotis myotis (expressed as a $\%$ of the total carotenoids recovered). Au - autumn, Sp - spring.

\begin{tabular}{|c|c|c|c|c|c|c|c|c|}
\hline \multirow{2}{*}{$\begin{array}{l}\text { Name of } \\
\text { carotenoid }\end{array}$} & \multicolumn{2}{|c|}{ Skin } & \multicolumn{2}{|c|}{ Muscles } & \multicolumn{2}{|c|}{ Liver } & \multicolumn{2}{|c|}{ Intestines } \\
\hline & $\mathrm{Au}$ & Sp & $\mathrm{Au}$ & $\mathrm{Sp}$ & $\mathrm{Au}$ & $\mathrm{Sp}$ & $\mathrm{Au}$ & $\mathrm{Sp}$ \\
\hline $\begin{array}{l}\beta \text {-carotene } \\
\text { echinenone }\end{array}$ & & 21.2 & & 30.0 & 22.1 & & 21.6 & 48.1 \\
\hline $\begin{array}{l}\text { echinenone } \\
\text { hydroxyechinenone }\end{array}$ & & & $\begin{array}{l}14.4 \\
12.6\end{array}$ & & & & & \\
\hline$\beta$-carotene epoxide & & & & & & 13.7 & & 23.2 \\
\hline $\begin{array}{l}\beta \text {-cryptoxanthin } \\
\text { canthaxanthin }\end{array}$ & 14.1 & & & 6.8 & 19.9 & & 9.2 & \\
\hline $\begin{array}{l}\text { canthaxanthin } \\
\text { lutein }\end{array}$ & & $\begin{array}{l}8.5 \\
7.4\end{array}$ & 15.9 & & & & $\begin{array}{l}12.8 \\
15.7\end{array}$ & \\
\hline lutein epoxide & 18.7 & 5.6 & & & 42.0 & 10.8 & $\begin{array}{l}10.7 \\
20.4\end{array}$ & 6.6 \\
\hline $\begin{array}{l}\text { isozeaxanthin } \\
\text { adonixanthin }\end{array}$ & 12.4 & & & & & & & 4.8 \\
\hline $\begin{array}{l}\text { adonixanthin } \\
\text { astaxanthin }\end{array}$ & & 12.5 & & & & $\begin{array}{r}12.4 \\
6.7\end{array}$ & & \\
\hline astaxanthin ester & 49.9 & & 13.3 & & 15.5 & 3.7 & & 11.0 \\
\hline $\begin{array}{l}\text { rhodoxanthin } \\
\text { aurochrome }\end{array}$ & & & & 22.1 & & 7.5 & & \\
\hline mutatochrome & & 13.0 & & 17.1 & & & & \\
\hline $\begin{array}{l}\text { mutatoxanthin } \\
\text { cryptoflavin }\end{array}$ & 3.0 & & 43.8 & 12.8 & & & & \\
\hline $\begin{array}{l}\text { cryptoflavin } \\
\beta \text {-apo-2'- }\end{array}$ & & & & & & & & 6.3 \\
\hline $\begin{array}{l}\text { carotenal } \\
\beta \text {-apo-8'- }\end{array}$ & 1.9 & 23.85 & & 11.2 & & 40.2 & 4.5 & \\
\hline carotenal & & 7.95 & & & & & 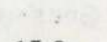 & \\
\hline Unknown & & & & & & & 15.8 & \\
\hline $\begin{array}{l}\text { Total content in } \\
\mu \mathrm{g} / \mathrm{g} \text { fresh weight }\end{array}$ & 1.055 & 0.890 & 0.101 & 0.099 & 0.706 & 4.245 & 1.287 & 2.404 \\
\hline
\end{tabular}

Some of the tissues of $M$. myotis examined were distinguished by particularly high carotenoid concentration, such as of $\beta$-carotene and its epoxide form, lutein and its epoxide form, astaxanthin ester, aurochrome, mutatoxanthin and $\beta$-apo-2'-carotenal. The greatest amount of carotenoids was found in the intestines, and least in the muscles (Table 1). The tissues of two females were distinguished by slightly higher total carotenoid concentration than in the two males (Fig. 1).

In Myotis nattereri 20 carotenoids were identified, among which those most frequently encountered in the tissues were: $\beta$-carotene and $\beta$-carotene epoxide. Echinenone and idoxanthin were found to be present in 
the liver of the individual caught in spring. In some tissues of $M$. nattereri the following carotenoids also occurred in relatively large amounts: $\beta$-carotene, $\beta$-cryptoxanthin, lutein, zeaxanthin, $\alpha$-doradexanthin, phoenicoxanthin and astaxanthin ester. As in the majority of the other bat species, greatest total amount of carotenoids occurred in the liver and intestines of Natterer's bat, while the smallest amount was found in its muscles (Table 2).

In Myotis brandtii only 7 carotenoids were identified, of which $\beta$-cryptoxanthin, canthaxanthin, zeaxanthin and isozeaxanthin occurred in all the three tissues examined. Zeaxanthin, isozeaxanthin and astaxanthin must also be allocated to the group of carotenoids dominating in Brandt':
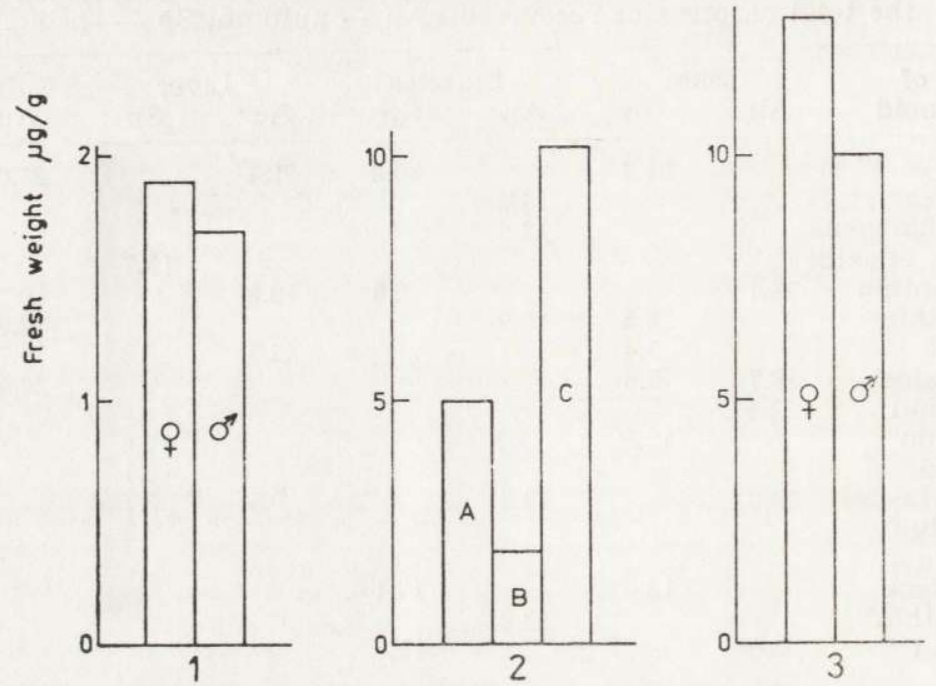

Fig. 1. Carotenoids contents in both sexes of Myotis myotis.

Fig. 2. Seasonal changes in carotenoids contents in males of Eptesicus serotinus. A, Nov. 21st; B, Dec. 20th; C, June 5th.

Fig. 3. Corotenoids contents in both sexes of Eptesicus serotinus.

bat. The greatest amount of carotenoids was contained in the intestines, and the smallest in muscles (Table 3).

The individuals of Myotis daubentoni examined contained 18 carotenoids, among which the presence of $\varepsilon$-carotene and rhodoxanthin deserve special mention. The following must be considered as carotenoids most frequently occurring in this species: $\beta$-carotene, $\beta$-cryptoxanthin, zeaxanthin, astaxanthin ester and $\beta$-apo-2'-carotenal. Such carotenoids as $\beta$-carotene, canthaxanthin, lutein, isozeaxanthin, zeaxanthin, rhodoxanthin and astaxanthin ester also occurred in relatively large amounts in some of the tissues of Daubenton's bat. The greatest 
Table 2

Seasonal changes in carotenoids contents of Myotis nattereri (expressed as a $\%$ of the total carotenoids recovered).

\begin{tabular}{|c|c|c|c|c|c|c|c|c|}
\hline \multirow{2}{*}{$\begin{array}{l}\text { Name of } \\
\text { carotenoid }\end{array}$} & \multicolumn{2}{|c|}{ Skin } & \multicolumn{2}{|c|}{ Muscles } & \multicolumn{2}{|c|}{ Liver } & \multicolumn{2}{|c|}{ Intestines } \\
\hline & $\mathrm{Au}$ & Sp & $\mathrm{Au}$ & $\mathrm{Sp}$ & $\mathrm{Au}$ & $\mathrm{Sp}$ & $\mathrm{Au}$ & $\mathrm{Sp}$ \\
\hline $\begin{array}{l}\beta \text {-carotene } \\
\text { echinenone } \\
\beta \text {-carotene }\end{array}$ & & 13.5 & & 9.0 & 5.7 & $\begin{array}{l}8.9 \\
6.6\end{array}$ & 28.9 & 11.5 \\
\hline epoxide & & & 15.0 & 10.8 & 6.1 & 9.3 & 13.4 & 13.1 \\
\hline$\beta$-cryptoxanthin & 24.9 & 33.5 & & 14.9 & & & 7.0 & 5.3 \\
\hline canthaxanthin & 6.0 & 12.9 & & & & & & 3.7 \\
\hline lutein & 12.2 & & 10.0 & 22.0 & & & & 11.7 \\
\hline lutein epoxide & 8.2 & & & 11.1 & 4.9 & 18.8 & 5.6 & \\
\hline isozeaxanthin & 19.0 & 8.1 & & 13.5 & & 10.8 & 13.1 & \\
\hline $\begin{array}{l}\text { zeaxanthin } \\
\alpha \text {-doradexanthin }\end{array}$ & & 20.7 & 19.9 & 10.3 & 21.8 & & & 40.8 \\
\hline adonixanthin & & & & & & 12.2 & & \\
\hline idoxanthin & & & & & & 2.9 & & \\
\hline $\begin{array}{l}\text { phoenicoxanthin } \\
\text { astaxanthin } \\
\text { astaxanthin }\end{array}$ & & 13.3 & 21.4 & & 16.5 & & 21.9 & 6.7 \\
\hline $\begin{array}{l}\text { ester } \\
\text { aurochrome }\end{array}$ & 13.7 & & 15.6 & & 37.6 & 6.65 & & \\
\hline $\begin{array}{l}\text { aurochrome } \\
\text { mutatochrome }\end{array}$ & 10.4 & & & 4.8 & & 17.2 & 6.1 & \\
\hline $\begin{array}{l}\text { cryptoflavin } \\
\beta \text {-apo-2'- }\end{array}$ & & & 9.5 & 3.6 & & & & 7.2 \\
\hline $\begin{array}{l}\text { carotenal } \\
\beta \text {-apo-8'- }\end{array}$ & & & & & 2.0 & 6.65 & 4.0 & \\
\hline $\begin{array}{l}\text { carotenal } \\
\text { Unknown }\end{array}$ & 4.6 & & & & & & & \\
\hline $\begin{array}{l}\text { Unknown } \\
\text { Total content in }\end{array}$ & & & 8.6 & & 5.4 & & & \\
\hline$\mu \mathrm{g} / \mathrm{g}$ fresh weight & 2.225 & 3.081 & 0.769 & 1.767 & 4.705 & 11.491 & 8.967 & 12.636 \\
\hline
\end{tabular}

Table 3

Carotenoids contents of Myotis brandtii in April 10, 1981 (expressed as a $\%$ of the total carotenoids recovered).

\begin{tabular}{lccc}
\hline Name of carotenoid & Muscles & Liver & Intestines \\
\hline B-cryptoxanthin & 20.8 & 11.8 & 16.4 \\
canthaxanthin & 11.4 & 19.9 & 8.0 \\
lutein epoxide & 12.3 & & 6.5 \\
zeaxanthin & 15.8 & 25.6 & 50.8 \\
isozeaxanthin & 10.0 & 33.7 & 18.3 \\
astaxanthin & 29.7 & 9.0 & \\
mutatochrome & & 4.104 & 8.455 \\
Total content, in $\mu \mathrm{g} / \mathrm{g}$ & 1.309 & & \\
fresh weight & & & \\
\hline
\end{tabular}

amounts of carotenoids were found in the liver, the minimum in muscles (Table 4).

In six individuals of Eptesicus serotinus 20 carotenoids were identified, among which the most frequently encountered were astaxanthin ester, isozeaxanthin, zeaxanthin, $\beta$-cryptoxanthin and $\beta$-carotene. The other carotenoids were found only in certain of the tissues with particularly 
abundant amounts of $\beta$-carotene (skin), $\beta$-cryptoxanthin (skin, muscles) canthaxanthin (muscles, intestines), zeaxanthin and isozeaxanthin (skin, liver, intestines), lutein (muscles, liver, intestines - particularly at the beginning of June) and astaxanthin ester (muscles, intestines). It must be emphasised that hydroxyechinenone was shown to be present in muscles, idoxanthin in the liver and embryo, and carotenoids from the apo-carotenals group (Table 5). The greatest amount of carotenoids was contained in the liver and intestines and the smallest in muscles. All the tissues examined from the individual from December contained far

Table 4

Seasonal changes in carotenoids contents of Myotis daubentoni (expressed as a $\%$ of the total carotenoids recovered).

\begin{tabular}{|c|c|c|c|c|c|c|c|c|}
\hline \multirow{2}{*}{$\begin{array}{l}\text { Name of } \\
\text { carotenoid }\end{array}$} & \multicolumn{2}{|c|}{ Skin } & \multicolumn{2}{|c|}{ Muscles } & \multicolumn{2}{|c|}{ Liver } & \multicolumn{2}{|c|}{ Intestines } \\
\hline & $\mathrm{Au}$ & $\mathrm{Sp}$ & $\mathrm{Au}$ & $\mathrm{Sp}$ & $\mathrm{Au}$ & $\mathrm{Sp}$ & $\mathrm{Au}$ & $\mathrm{Sp}$ \\
\hline$\beta$-carotene & & 5.2 & 19.4 & & 30.3 & 27.8 & 5.2 & 17.5 \\
\hline $\begin{array}{l}\varepsilon \text {-carotene } \\
\beta \text {-carotene }\end{array}$ & & & & & & 7.7 & & \\
\hline epoxide & & 5.7 & 19.0 & & & & 12.6 & \\
\hline$\beta$-cryptoxanthin & 4.6 & 6.6 & 9.8 & 11.5 & 16.0 & & 8.7 & 5.3 \\
\hline canthaxanthin & 5.3 & & 30.1 & & 11.4 & & 28.6 & 7.4 \\
\hline lutein & & & & 33.4 & & 27.0 & & \\
\hline lutein epoxide & 4.6 & 1.8 & 15.4 & 7.4 & & & 257 & \\
\hline isozeaxanthin & 17.4 & 3.5 & & & 27.9 & & 25.7 & 10.1 \\
\hline $\begin{array}{l}\text { zeaxanthin } \\
\alpha \text {-doradexanthin }\end{array}$ & 5.0 & 5.1 & & 4.2 & & 27.6 & & $\begin{array}{r}9.3 \\
10.5\end{array}$ \\
\hline adonixanthin & 10.3 & 9.9 & & 19.1 & & & & \\
\hline $\begin{array}{l}\text { rhodoxanthin } \\
\text { astaxanthin }\end{array}$ & 22.0 & & & & & & & 6.1 \\
\hline ester & 20.6 & 7.4 & 2.6 & 16.2 & 5.1 & 3.6 & 10.5 & \\
\hline $\begin{array}{l}\text { aurochrome } \\
\text { mutatochrome }\end{array}$ & & & & 8.2 & & & 6.2 & \\
\hline mutatoxanthin & & & & & 7.2 & & & \\
\hline $\begin{array}{l}\text { cryptoflavin } \\
\beta \text {-apo-2'- }\end{array}$ & & & 1.8 & & & & & 8.4 \\
\hline $\begin{array}{l}\text { carotenal } \\
\text { Total content in }\end{array}$ & 10.2 & 3.5 & 1.9 & & 2.1 & & 2.5 & 1.7 \\
\hline $\begin{array}{l}\text { Total content in } \\
\mu \mathrm{g} / \mathrm{g} \text { fresh weight }\end{array}$ & 4.885 & 6.327 & 2.349 & 1.282 & 11.024 & 12.297 & 6.594 & 1.435 \\
\hline
\end{tabular}

fewer carotenoids than in the case of the individuals from November and from June (Fig. 2). As in the case of M. myotis, a slightly greater amount of carotenoids was found in female tissues (Fig. 3). Furthermore, certain carotenoids proved to dominate in the male, and others in the female and serotine embryo of female sex (Table 5).

In the case of Plecotus auritus the 12 carotenoids found in the other five species were found to be present in autumn. The following occurred in large amounts: $\beta$-carotene, $\beta$-carotene epoxide, canthaxanthin, lutein, isozeaxanthin and astaxanthin ester. As in the other species of bat, the greatest total concentration of carotenoids occurred in the intestines and liver, and a smaller amount in the muscles of $P$, auritus (Table 6). 
The results obtained show that the concentrations of carotenoids in four different tissues of 6 species of bat are subject to seasonal (Table $1-6$ ), sex (Fig. 1 and 3 ) and age variation (Table 5). The different species of Vespertilionidae differ qualitatively in respect of the composition of the carotenoids in the tissues examined (Table $1-6$ ), and some of these pigments are proper only to certain species of bat (Table 7). The majority of the carotenoids occurring in bat tissues were also found in the tissues of the insect prey which form their food (Table 8).

\section{DISCUSSION}

The majority of the carotenoids identified in bats have already been shown to occur in other species of mammals (Czeczuga \& Malzahn, 1980), but even so the fact that other more rarely encountered carotenoids were also found in some of the bats deserves particular mention. These are: $\varepsilon$-carotene, hitherto known in insects and fish, echinenone and its derivative-hydroxyechinenone, so far known in insects and fish, $\alpha$-doradexanthin known from its wider occurrence in molluses, crustaceans and fish, idoxanthin occurring in marine crustaceans and fish, rhodoxanthin known to occur in several species of fish. $\beta$-apo-2'-carotenal and $\beta$-apo-8'-carotenal, on the other hand, have so far been shown to occur only in birds and mammals, and their presence in animal tissues is connected with transformation of $\beta$-carotene into vitamin A (Thommen, 1961; Bauernfeind, 1972).

As is well known Microchiroptera of the temperate zones feed chiefly on insects, although there have been reports that terrestrial molluses (Sologor \& Petrusenko, 1973) and aquatic crustaceans and fish also perticipate in their food. The composition of the food consumed by the majority of the bat species we examined is now well known. The food of Myotis myotis consists chiefly of slow-flying Carabidae, in addition to representatives of Araneidea, Hymenoptera and Formicoidea, obtained by means of selecting prey of larger dimensions. M. myotis in manifesting longlasting nocturnal food activity tends to consume a very small variety of food (composed of several components of considerable importance). Ecological descriptions of different prey species show that $M$. myotis prefers as its hunting grounds the edges of tree stands and shelterbelts, which provide optimum amounts of food (Bauerová, 1978). Whiskered bats from Finland feed chiefly on Lepidoptera $(75-80 \%)$, Diptera, Trichoptera, Ephemeroptera and Plecoptera (Nyholm, 1965). The composition of the food of Myotis daubentoni depends to a great degree on the kind of biotope, and exhibits geographical variability. As shown by results of studies in Finland (Nyholm, 1965) Lepidoptera and 
Table 5

Seasonal changes in carotenoids contents in male, female and embryo of Eptesicus

\begin{tabular}{|c|c|c|c|c|c|c|c|c|c|c|}
\hline \multirow[b]{2}{*}{ Name of carotenold } & \multicolumn{5}{|c|}{ Sk1n } & \multicolumn{5}{|c|}{ Kuscies } \\
\hline & $\begin{array}{l}\text { Nov. } 21 \\
M\end{array}$ & ilec. 20 & $\begin{array}{c}\text { June } 5 \\
\text { M }\end{array}$ & $\begin{array}{c}5 \text { June } 13 \\
M\end{array}$ & $\begin{array}{c}\text { June } 13 \\
F\end{array}$ & Nor. 21 & $\begin{array}{c}\text { Dec. } 20 \\
\text { M }\end{array}$ & $\begin{array}{c}\text { June } \\
\mathrm{M}\end{array}$ & $\begin{array}{c}5 \text { dune } 13 \\
\times\end{array}$ & $\begin{array}{c}3 \text { june } 13 \\
F\end{array}$ \\
\hline A-carotene & 4.9 & 24.4 & & & & & & & & \\
\hline hydroxyech1nenone & & & & & & & 8. 9 & & & \\
\hline$\beta$-carotene epoxide & 2.6 & & & 21.7 & & & & & & \\
\hline$\beta$-cyptoxanthin & 8.4 & 23.5 & & & 28.5 & 24.5 & 12.0 & & 8. 1 & 11.6 \\
\hline canthaxanthin & 9.5 & & 4.2 & & 12.3 & 21.1 & 15.0 & & 2.6 & \\
\hline lite1n & & & & & & & & 77.2 & & \\
\hline Iute1n epoxide & & & & 12.3 & 14.6 & 19.6 & & & & 32.2 \\
\hline zeaxanthin & 9.2 & 10.7 & 59.5 & & 19.8 & & & & 47. C & 16.4 \\
\hline 1sozeaxanth1n & 15.6 & 24.2 & 19.4 & 40.1 & 17.1 & 11.2 & 17.1 & 7.6 & 42.3 & 16.3 \\
\hline$\alpha$-doradexanthin & 13.3 & & & & & & & & & \\
\hline adonixanth1n & 10.2 & & 16.9 & & & & & 15.2 & & 17.8 \\
\hline 1doxanth1n & & & & & & & & & & \\
\hline astaxanthin & & & & & & 6.7 & & & & \\
\hline $\begin{array}{l}\text { astaxanthin ester } \\
\text { rhodoxanthin }\end{array}$ & 19.7 & 8.0 & & 7.8 & & 12.2 & 25.4 & & & 3.6 \\
\hline mutatochrome & & & & & & & 12.2 & & & \\
\hline mutatoxanthin & 4.4 & & & & & & & & & \\
\hline cryptoflavin & & 13.9 & & & 4.5 & & & & & \\
\hline - -apo-2'-carotenal & 2.2 & 6.0 & & 18.1 & & & & & & \\
\hline -apo-8'-carotenal & & & & & & & 9.4 & & & \\
\hline ünknown & & & & & 3.2 & & & & & 2.1 \\
\hline $\begin{array}{l}\text { Total content in } \\
\text { ug/g fresh we1ght }\end{array}$ & 1.472 & 1.219 & 1.593 & 1.057 & 1.916 & 0.932 & 0.479 & $1.4 k 1$ & 2.496 & 1.496 \\
\hline
\end{tabular}

Table 6

Carotenoids contents of Plecotus auritus in Nov. 21, 1979 (expressed as a $\%$ of the total carotenoids recovered).

\begin{tabular}{|c|c|c|c|c|}
\hline Name of carotenoid & Skin & Muscles & Liver & Intestines \\
\hline $\begin{array}{l}\beta \text {-carotene } \\
\text { echinenone }\end{array}$ & 12.5 & & 13.6 & 26.7 \\
\hline hydroxyechinenone & & 7.2 & & \\
\hline$\beta$-carotene epoxide & & & 26.8 & \\
\hline $\begin{array}{l}\beta \text {-cryptoxanthin } \\
\text { canthaxanthin }\end{array}$ & $\begin{array}{l}19.2 \\
45.3\end{array}$ & & & \\
\hline lutein & & 14.6 & 25.4 & \\
\hline lutein epoxide & & 19.6 & & \\
\hline isozeaxanthin & & 16.0 & 26.3 & 47.5 \\
\hline $\begin{array}{l}\text { zeaxanthin } \\
\text { astaxanthin ester }\end{array}$ & & $\begin{array}{r}7.5 \\
35.1\end{array}$ & 7.9 & 8.6 \\
\hline mutatochrome & & & & 17.2 \\
\hline $\begin{array}{l}\text { unknown } \\
\text { Total content in }\end{array}$ & 23.0 & & & \\
\hline$\mu \mathrm{g} / \mathrm{g}$ fresh weigt & 1.146 & 0.424 & 3.845 & 6.155 \\
\hline
\end{tabular}


serotinus (expressed as a $\%$ of the total carotenoids recovered). M, male; F, female.

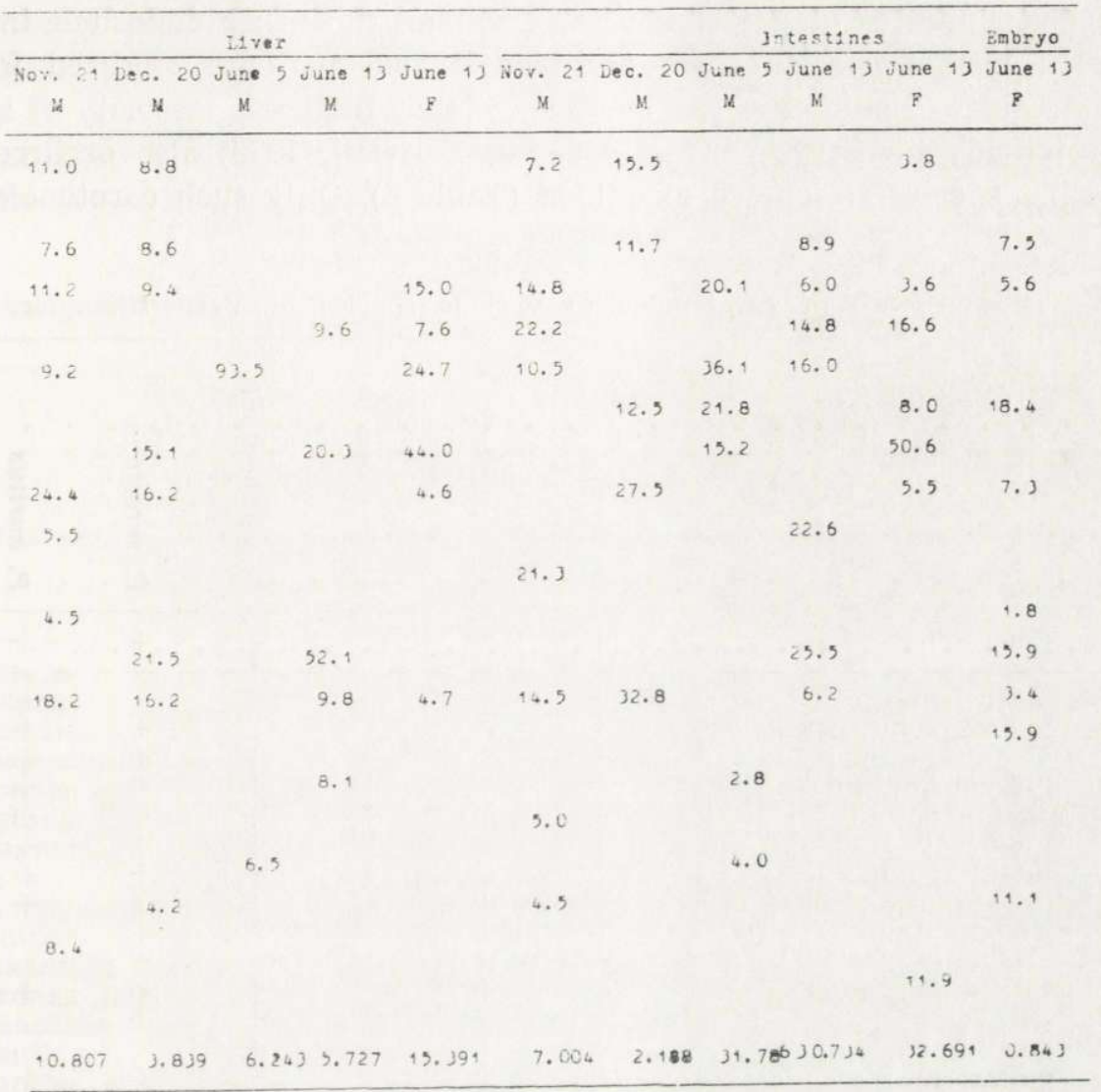

Diptera predominate in the food of $M$. daubentoni, whereas in western France the remains of insects belonging to Tabanidae and remains of crustaceans from Ostracoda and Cladocera, and even particles of fish, predominated in its diet (Brosset \& Deboutteville, 1936). Analysis of guano and the stomach contents of $E$. serotinus showed that $99.8 \%$ of its food from the qualitative aspect was formed by insects, and only $0.14 \%$ by molluscs. The following predominated among insects remains: Carabidae, remaining species of Coleoptera, Diptera, Simuliidae and Hymenoptera (Sologor \& Petrusenko, 1973). Krauss (1978) found in his studies that Noctuidae - Triphaena pronuba L., Parastichtis monoglypha Hufn. and Phytometra gamma L. predominated in the diet of the common long-eared bat.

It can be seen from the above data that the dominating component 
of the food consumed by the bat species examined are terrestrial insects. It may therefore be concluded that it is together with this food that bats consume carotenoids. Part of them are probably deposited in different tissues, while others are transformed to more oxidized forms. The results of studies so far made show that the great majority of insect carotenoids (Czeczuga, 1976, 1980a, b; Feltwell, 1979) also occurred in the bat species which we examined (Table 8). Only such carotenoids as

Table 7

The presence of carotenoids in various species of Vespertilionidae.

\begin{tabular}{|c|c|c|c|c|c|c|}
\hline Name of carotenoid & 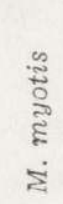 & 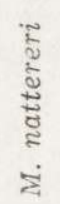 & 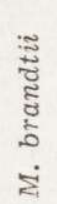 & 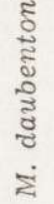 & 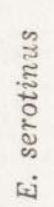 & 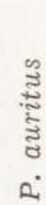 \\
\hline $\begin{array}{l}\beta \text {-carotene } \\
\varepsilon \text {-carotene } \\
\text { echinenone } \\
\text { hydroxyechinenone } \\
\beta \text {-carotene epoxide } \\
\beta \text {-cryptoxanthin } \\
\text { canthaxanthin } \\
\text { lutein } \\
\text { lutein epoxide } \\
\text { isozeaxanthin } \\
\text { adonixanthin } \\
\text { astaxanthin } \\
\text { astaxanthin ester } \\
\text { rhodoxanthin } \\
\text { aurochrome } \\
\text { mutatochrome } \\
\text { mutatoxanthin } \\
\text { cryptoflavin } \\
\text { zeaxanthin } \\
\alpha \text {-doradexanthin } \\
\text { idoxanthin } \\
\text { phoenicoxanthin } \\
\beta \text {-apo-2'-carotenal } \\
\beta \text {-apo-8'-carotenal } \\
\text { Unknown }\end{array}$ & $\begin{array}{l}+ \\
+ \\
+ \\
+ \\
+ \\
+ \\
+ \\
+ \\
+ \\
+ \\
+ \\
+ \\
+ \\
+ \\
+ \\
+ \\
+ \\
+\end{array}$ & $\begin{array}{l}+ \\
+ \\
+ \\
+ \\
+ \\
+ \\
+ \\
+ \\
+ \\
+ \\
+ \\
+ \\
+ \\
+ \\
+ \\
+ \\
+ \\
+ \\
+ \\
+\end{array}$ & $\begin{array}{l}+ \\
+ \\
+ \\
+ \\
+\end{array}$ & $\begin{array}{l}+ \\
+ \\
+ \\
+ \\
+ \\
+ \\
+ \\
+ \\
+ \\
+ \\
+ \\
+ \\
+ \\
+ \\
+ \\
+\end{array}$ & $\begin{array}{l}+ \\
+ \\
+ \\
+ \\
+ \\
+ \\
+ \\
+ \\
+ \\
+ \\
+ \\
+ \\
+ \\
+ \\
+ \\
+ \\
+ \\
+ \\
+ \\
+\end{array}$ & $\begin{array}{l}+ \\
+ \\
+ \\
+ \\
+ \\
+ \\
+ \\
+ \\
+\end{array}$ \\
\hline
\end{tabular}

hydroxyechinenone, adonixanthin, idoxanthin, rhodoxanthin, cryptoflavin and carotenoids from the apo-carotenal groups have not hitherto been shown in insects. It may therefore be assumed that these carotenoids are formed in bat organisms from their precursors consumed together with food.

When the qualitative composition of carotenoids of the bats examined were compared in autumn and spring, some seasonal differences were observed. In autumn bats tissues usually contained the ester form of 
astaxanthin, which was not observed in spring (an exception to this is E. serotinus from the first half of June). In addition M. myotis, $M$. nattereri and $M$. daubentoni, available in spring, were distinguished by a generally greater concentration of carotenoids than found for individuals in autumn, i.e., examined during the initial phase of hibernation. Probably these bats flew about in their search for food and consequently the losses of carotenoids taking place during the course of hiberna-

Table 8

The distribution of carotenoids in bats and insects found as prey in chiropteran food. References see text.

\begin{tabular}{|c|c|c|c|c|c|c|c|c|c|c|c|c|}
\hline Name of carotenoid & 㟧 & 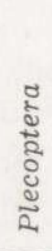 & 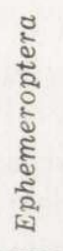 & 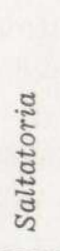 & 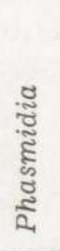 & 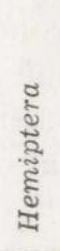 & 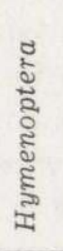 & 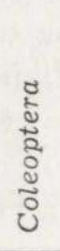 & 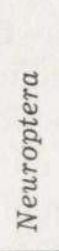 & 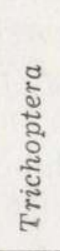 & 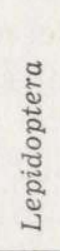 & 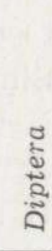 \\
\hline$\beta$-carotene & + & & & + & + & + & + & + & & + & + & + \\
\hline $\begin{array}{l}\text { E-carotene } \\
\text { echinenone }\end{array}$ & $\begin{array}{l}+ \\
+\end{array}$ & & & & & $\stackrel{+}{+}$ & + & + & + & & & t \\
\hline $\begin{array}{l}\text { hydroxyechinenone } \\
\beta \text {-carotene epoxide }\end{array}$ & $\begin{array}{l}+ \\
+\end{array}$ & & & & & + & + & + & + & & + & \\
\hline $\begin{array}{l}\beta \text {-cryptoxanthin } \\
\text { canthaxanthin }\end{array}$ & + & + & + & & & + & + & + & + & & + & + \\
\hline $\begin{array}{l}\text { lutein } \\
\text { lutein epoxide }\end{array}$ & + & & & + & & + & + & $\begin{array}{l}+ \\
+\end{array}$ & + & & + & + \\
\hline $\begin{array}{l}\text { lutein epoxide } \\
\text { zeaxanthin }\end{array}$ & + & + & $\begin{array}{l}+ \\
+\end{array}$ & & & $\begin{array}{l}+ \\
+\end{array}$ & $\begin{array}{l}+ \\
+\end{array}$ & $\begin{array}{l}+ \\
+\end{array}$ & $\begin{array}{l}+ \\
+\end{array}$ & & $\begin{array}{l}+ \\
+\end{array}$ & + \\
\hline $\begin{array}{l}\text { isozeaxanthin } \\
\alpha \text {-doradexanthin } \\
\text { adonixanthin }\end{array}$ & $\begin{array}{l}+ \\
+ \\
+\end{array}$ & & + & + & + & & + & & & & + & \\
\hline astaxanthin & + & & + & + & & & + & + & + & & + & + \\
\hline $\begin{array}{l}\text { astaxanthin ester } \\
\text { idoxanthin } \\
\text { rhodoxanthin }\end{array}$ & $\begin{array}{l}+ \\
+ \\
+\end{array}$ & & & & & + & & + & & & + & \\
\hline $\begin{array}{l}\text { rhodoxanthin } \\
\text { phoenicoxanthin } \\
\text { aurochrome }\end{array}$ & + & & & & & & + & & & & + & \\
\hline $\begin{array}{l}\text { mutatochrome } \\
\text { mutatoxanthin }\end{array}$ & + & + & + & & & & & + & + & & + & \\
\hline $\begin{array}{l}\text { mutatoxanthin } \\
\text { cryptoflavin }\end{array}$ & + & & & & & & & & + & & & \\
\hline $\begin{array}{l}\beta \text {-apo-2'-carotenal } \\
\beta \text {-apo-8'-carotenal } \\
\beta\end{array}$ & + & & & & & & & & & & & \\
\hline unknown & & & & & & & & & + & & & \\
\hline
\end{tabular}

tion were quickly supplemented. Confirmation for our assumption is supplied by the results from Puławy obtained during Krzanowski's studies (1961) and patterns of winter activity found in three species of the genus Myotis in Holland (Daan, 1973). Krzanowski (1961) found that there was no coincidence in time between the start of hibernation and autumn appearance in the cave of $M$. myotis and $M$. nattereri. These species in October, and $M$. nattereri even in November, fly out from 
the cave to go hunting, reaching the peak increase in body weight during the second half of October and November. In many cases this author observed increase in body weight during hibernation, despite the low temperatures inside the cave. Daan (1973) found that in the case of Dutch bats flights into the cave take place gradually and last from September to December, while flights out from the cave for the summer period last from mid-March to mid-April. Although the turnover of this population is not great in winter, about $10 \%$ of the bats decide to leave the cave after awaking, usually migrating in autumn for a distance of not more than 1 kilometer.

The data relating to males of E. serotinus (Fig. 2) would'seem to point to decrease in the total concentration of carotenoids during hibernation. Similarly, reduction in the level of vitamin A contents in the liver of Nyctalus noctula (Schreber) and Pipistrellus pipistrellus (Schreber) during hibernation was also observed by Krochko \& Semistrok (1973). It must be remembered that the majority of carotenoids form the provitamin A. We also found, using M. myotis and E. serotinus as examples, a generally higher concentration of carotenoids in female tissues (Fig. 1 and 3 ). The results we obtained in relation to sex differences in carotenoid concentration are in complete agreement with the observations of other authors relating to bats (Krochko \& Semistrok, 1973), rodents (Czeczuga \& Malzahn, 1980) and man (Pearson, 1967).

Although carotenoid concentration in different bat tissues appears to depend on a large number of factors (species, age, sex, season, food composition), the results obtained may in the future find wider application as a research method in comparative physiology and taxonomy and its new branch - chemosystematics (cf. Liaaen-Jensen, 1977).

Acknowledgments: The authors wish to convey their thanks to Messrs S. Buszko, J. Dackiewicz and G. Lesiński for their assistance in collecting material under particularly difficult field conditions.

\section{REFERENCES}

1. Bauernfeind J. C., 1972: Carotenoid vitamin A precursors and analogs in foods and feeds. J. Agr. Food Chem., 20: 456-473.

2. Bauerová Z., 1978: Contribution to the trophic ecology of Myotis myotis. Folia Zool., 27: 305-316.

3. Brosset A. \& Deboutteville C. D., 1966: Le régime alimentaire du vespertilion de Daubenton Myotis daubentoni. Mammalia, 30: 247-251.

4. Czeczuga B., 1976: Investigations on the carotenoids in nineteen species of Aphids and their host plants. Zool. Pol., 25: 27-45.

5. Czeczuga B. \& Czerpak R., 1976: Carotenoids in fish. VII. The kind of food and the content of carotenoids and vitamin A in Carassius carassius (L.) and Leucaspius delineatus (Heck.). Acta hydrobiol., 18: 1-21. 
6. Czeczuga B., 1980a: Investigations on carotenoids in insects. II. Water insects. Acta hydrobiol., 22: 29-35.

7. Czeczuga B., 1980b: Investigations on carotenoids in insects. III. The presence of carotenoids in representatives of various orders. Zool. Pol., 28: 85-96.

8. Czeczuga B. \& Malzahn E., 1980: Carotenoid contents in mammals. I. Apodemus flavicollis and Clethrionomys glareolus. Acta theriol., 25: 501-509.

9. Czeczuga B. \& Ruprecht A. L., 1981: Carotenoid content in the bat at start and at end of the hibernation. First European Symposium on Bat Research. Bonn, March 16th-20th 1981.

10. Daan S., 1973: Activity during natural hibernation in three species of vespertilionid bats. Neth. J. Zool., 23: 1-71.

11. Feltwell J., 1979: The distribution of carotenoids in insects. [In: "Biochemical insects"]. London Pergamon Press, 277-307.

12. Krochko Yu. \& Semistrok L. D., 1973: Izmenenije soderžanija vitamina A v pečeni večernicy ryžej i netopyrja-karlika v period zimnej spjački v uslovijah Zakarpatskoj Oblasti. Vestnik zool., 1: 78-80.

13. Krauss A., 1978: Materialien zur Kenntnis der Ernährungsbiologie des Braunen Langohrs (Plecotus auritus L.) (Mammalia, Chiroptera). Zool. Abh. Mus. Tierk. Dresden, 34: 325-337.

14. Krzanowski A., 1961: Weight dynamics of bats wintering in the cave at Pulawy (Poland). Acta theriol., 4: 249-264.

15. Liaaen-Jensen S., 1977: Algal carotenoids and chemosystematics. Marine Natural Productions Chemistry, Eds D. J. Faulkner and W. H. Fenical, 239-259.

16. Nyholm E. S., 1965: Zur Okologie von Myotis mystacinus (Leisl.) und M. daubentoni (Leisl.) (Chiroptera). Ann. zool. Fenn., 2: 77-123.

17. Pearson W. N., 1967: Blood and urinary vitamin levels as potential indices of body stores. Am. J. Clin. Natr., 20: 514-519.

18. Sologor E. A. \& Petrusenko A. A., 1973: K izučeniju pitanija rukokrylyh (Chiroptera) Srednego Predneprov'ja. Vestnik zool., 3: 40-45.

19. Thommen H., 1961: Studies on the metabolism of $\beta$-apo-8'-carotenal. Chimia, 15: $433-434$.

Accented, November 25, 1981. 
Bazyli CZECZUGA i Andrzej L. RUPRECHT

\section{ZAWARTOSC KAROTENOIDÓW U SSAKÓW. II. KAROTENOIDY \\ NIEKTORYCH MROCZKOWATYCH (VESPERTILIONIDAE) \\ W ASPEKCIE ZMIENNOSCI SEZONOWEJ}

\section{Streszczenie}

Autorzy stosując kolumnową i cienkowarstwową chromatografię badali występowanie i zawartość karotenoidów w skórze, mięśniach, wątrobie i jelitach u nocków: dużego, Natterera, Brandta i rudego oraz u mroczka późnego i gacka wielkoucha w aspekcie zmienności sezonowej, płciowej oraz w przypadku $E$. serotinus - wiekowej. Maksymalna koncentracja korotenoidów występuje w jelitach i wątrobie, mniejsza zaś w mięśniach u wszystkich sześciu gatunków nietoperzy (Tabele 1-6). Ilość wykrytych karotenoidów wahała się u badanych gatunków nietoperzy od 7 do 20 , przy czym występowanie niektórych z nich było charakterystyczne dla określonych gatunków (Tabela 7). Większość karotenoidów obecna w tkankach nietoperzy była także stwierdzona w tkankach owadów-ofiar stanowiących ich pokarm (Tabela 8). Inne karotenoidy charakterystyczne dla nietoperzy a nie występujące $w$ organizmach owadów przypuszczalnie syntezowane są w tkankach nietoperzy ze swych prekursorów pobranych z pokarmem. Sukcesywny spadek zawartości karotenoidów czterech tkanek cechuje początek trwania hibernacji u mroczka późnego (Fig. 2). Natomiast ogólna zawartość karotenoidów $\mathrm{u}$ trzech gatunków nocków (duży, Natterera i rudy) jest u nich wyższa pod koniec hibernacji. Przemawia to za możliwością korzystania przez te gatunki $\mathrm{z}$ dodatkowych źródeł pokarmu podczas okresu zimowego. Srednia zawartość karotenoidów u samic nocka dużego i mroczka późnego była większa aniżeli u samców (Fig. 1 i 3). 